\title{
A Two-Staged Approach to Technology Entrepreneurship: Differential Effects of Intellectual Property Rights
} Saurav Pathak \& Etayankara Muralidharan

\author{
' Intellectual-property rules are clearly necessary to spur innovation: if every \\ invention could be stolen, or every new drug immediately copied, few people \\ would invest in innovation. But too much protection can strangle \\ competition and can limit what economists call 'incremental innovation' - \\ innovations that build, in some way, on others."
}

James Surowiecki

American Journalist

\begin{abstract}
In this article we examine how the strength of the intellectual property rights (IPR) regime drives technology entrepreneurship innovation (TEI). The latter is comprised of novel unfamiliar technological products and new business models, which in turn lead to new product-market combinations. We consider TEI to be a two-stage process that involves access to and use of new technologies and technological resources by entrepreneurs. While stronger IPR may constrain easy availability of new technologies and technological resources for entrepreneurs, using technology itself helps lead to TEI. We suggest that stronger IPR regimes could lead to TEI. The positive effect of TEI is felt through easier accessibility to the latest technologies and technology resources by entrepreneurs. Our model contributes to understanding the effect of strong IPR regimes on different stages of the innovation process.
\end{abstract}

\section{Introduction}

Technology entrepreneurship (TE), as defined by Bailetti (2012), involves assembling and deploying specialized knowledge and heterogeneous assets to advance knowledge that captures value for the entrepreneur. From this, we infer that value capture through TE involves the use of technology by entrepreneurs to develop innovations, such as or through novel unfamiliar technological products (goods or services), as well as new business models that lead to new product-market combinations (Giones et al., 2013; Pathak et al., 2013; Pathak et al., 2014; Westerlund et al., 2014). The above is in line with the economist Joseph Schumpeter's theory of entrepreneurship (Schumpeter, 1912), wherein invention is considered as the creation of new ideas, which are turned into technologies, and innovation is commercialization or recombination of technology into marketable forms of production.

In this article we define such innovations as technology entrepreneurship innovation (TEI) and use this term interchangeably with entrepreneurial innovation and/or just innovation, throughout. Further, since entrepreneurial behaviors may in part be shaped by the context in which such behaviors are performed (Welter, 2011), the guiding question of this article is: How does an intellectual property rights (IPR) regime, as a national level contextual factor, drive TEI?

Extant literature offers mixed evidence on the influence of Intellectual Property Rights (IPR) on TEI. Acs and Sanders (2008) suggest that strong IPR can stifle commercialization (by entrepreneurs) by putting too much power in the hands of inventors. Studies from this perspective suggest potential negative effects of strong IPR on TEI (Autio \& Acs, 2010). From a different perspective, the more conventional view (from neoclassical economics) suggests that the IPR regime provides incentives for inventors to invent more, by allowing them to recoup their investments in research and development (R\&D) (by extracting value from monopoly rights over invention or innovation). Studies that follow the conventional view consider inventions as public goods and therefore posit a positive association between strong IPR enforcement and TEI (Estrin et al., 2013; Hartmann, 2014). 


\section{A Two-Staged Approach to Technology Entrepreneurship: Differential Effects of Intellectual Property Rights Saurav Pathak \& Etayankara Muralidharan}

Highly stringent IPR regimes may therefore hinder knowledge spillover effects that could be critical for TEI. On the other hand, the stringency of IPR regimes and the value they may have for a technology entrepreneur's utility maximization could be an incentive that motivates more and more entrepreneurs to engage in TEI. The contrasting inferences involved suggest that probably more needs to be understood about the IPR-TEI relationship in order to predict the influence of IPR on TEI more accurately. One of the reasons that could contribute to the above contrasting inferences could be how we conceptualize the process of making TEI, which could then help understand how IPR influences TEI.

In a bid to do so, we approached the conceptualization of TEI from a stage-based perspective -that TEI as we know or define it may be the end outcome, but that it progresses through stages. Each stage is influenced differently by IPR. In this regard, we posit that TEI is a two-staged process: (a) first, involving accessibility to the latest technologies by entrepreneurs, and thereafter, (b) the use of the new technologies in TEI. The way IPR regimes influence the above two stages will then determine the overall influence of IPR on TEI.

In short, we attempt in this paper to resolve the mixed influences of IPR by offering a process-based approach to technology entrepreneurship. The paper proceeds by reviewing prior studies that have examined technology use in entrepreneurship, entrepreneurial innovation, and the influence of IPR. We then introduce our two-stage conceptual model, discuss the implications of our study for future research, and conclude.

\section{Theory Background}

\section{Innovation as a stage-based process}

Innovation can be considered as an idea, a product, a program, or a technology that is new to the adopting organization (Rogers \& Shoemaker, 1971). Many scholars have suggested that the process of innovation diffusion is stage-based. Rogers (1995) suggested five stages: knowledge, persuasion, decision, implementation, and confirmation.

In studying innovations in organizations, scholars have been typically interested in the stages of initiation, adoption, and diffusion of innovation (Nystrom et al., 2002). Information technology innovation adoption in organizations is considered as a sequence of stages that progress from initiation to adoption-decision to implementation (Hameed et al., 2012). Further, in arguing that innovation is a sequence of stages, rather than an event, scholars have suggested that there are different concerns at the various stages (Greenhalgh et al., 2008). Therefore, antecedents of innovation may have different effects at these various stages. In discussing initiation, adoption decision, and implementation of innovations as key phases in innovation adoption, Damanpour et al. (2006) argue that environmental, organizational, and managerial characteristics have different effects at these several stages. We now examine entrepreneurship as a stagebased process in technology innovation.

\section{Entrepreneurship as a stage-based process}

We draw insights from studies on the life-cycle of new ventures that entrepreneurial activity is also stagebased. Reflecting on the dominant problems during a venture's growth process, Kazanjian and Drazin (1990) suggested four stages in the life cycle of new ventures: conception and development, commercialization, growth, and stability. Similarly, other studies have empirically distinguished gestation, infancy, and adolescence as key stages of the life-cycle of new ventures (Korunka et al., 2003). With the aim of helping entrepreneurs navigate through transitions during the life-cycle of their businesses, and focusing on hightechnology ventures, Hanks and colleagues (1993) demonstrated using cluster analysis that each life-cycle stage consists of a unique configuration of factors relating to organizational context and structure. Bhave (1994) created a more granular process-based model of entrepreneurial venture creation, also dividing it into four stages: opportunity stage, technology set-up stage, organization-creation stage, and exchange stage. The stages entailed in the entrepreneurial process can therefore be demarcated by key transition points such as, business concept identification, commitment to begin, production technology set-up, and the first actual sale. In our conceptualization we suggest TEI to be a two-stage process, that is, 1. entrepreneurs accessing new technology or new technological resources, and 2. entrepreneurs using technology for TEIs.

\section{Technology accessibility and TEI}

Whether entrepreneurs develop new technologies or use the latest ones in their ventures, having access to such technologies is itself important for entrepreneurs engaged in TEI (Fagerberg, 1987). Knowledge spillovers are among the most important drivers of TEIs (Pathak et 


\section{A Two-Staged Approach to Technology Entrepreneurship: Differential Effects of Intellectual Property Rights Saurav Pathak \& Etayankara Muralidharan}

al., 2013). Entrepreneurs' talents and abilities to exploit spillovers from extant technological and knowledge bases leads to innovations (Acs \& Audretsch, 1988). Lack of access to new technology constrains entrepreneurial intentions and reduces expectations of net gains from entrepreneurial behavior (Pathak et al., 2013). It is also suggested that using the latest technologies for generating innovations may help entrepreneurs achieve competitive parity with incumbents (Fleming, 2001).

In sum, while most innovations in goods and services result from awareness and imitation of existing resources (Glass \& Saggi, 2002), the key to TEI may well be the ease of accessibility and usage of new technologies. Extant literature views national institutions as providing the incentive structures that signal the accessibility and degree of ease with which technology entrepreneurs can acquire, mobilize, blend, and recombine resources to introduce TEIs in the market (Douglas \& Shepherd, 2002). Specifically, policies concerning IPR are particularly important in that they can either foster or deter TE.

\section{Intellectual property rights and technology \\ entrepreneurship}

While the value of intellectual property is central to the strategy of technology companies (Henry, 2011), the extent of IPR enforcement could simultaneously facilitate and constrain TE (Pathak et al., 2013). When IPR regimes are strict, technology entrepreneurs perceive that their TEIs are protected from competitors (Acs \& Sanders, 2008). It may also enhance an entrepreneur's access to investment capital from risk averse sources (Pathak et al., 2013). On the other hand, strong IPR regimes may restrict accessibility to the latest available components and resources, by increasing early costs and reducing access to key technologies (Autio \& Acs, 2010), thus impeding the imitative and re-combinatory processes that yield TEIs (Fleming, 2001). Specifically, high costs could deter TEIs from entrepreneurs' quests to exploit new combinations of technology resources strongly protected by IPRs (for example, patented or copyrighted components) (Pathak et al., 2013). In view of the above mixed effects regarding the strength of IPR on TEI as observed by extant research, it may be that the IPR regime's design relevant to the stage at which the innovation is in matters more. In short, strong IPR could be good for all, if it is designed with both the interests of incumbents and new entrants in mind. In the next sections, we develop propositions that comprise our model regarding the influence of IPR on TEI.

\section{Proposition Development}

\section{IPR and technology accessibility for TEI}

The knowledge spillover theory of entrepreneurship suggests that endogenous forces first create knowledge, and then spillovers allow entrepreneurs to spot such knowledge and exploit opportunities (Acs et al., 2009). It is therefore the entrepreneur's talents and abilities to exploit such knowledge spillovers from an extant knowledge base that lead to innovations through recombinatory processes, despite incumbent firms bringing new technologies to the market (Acs \& Audretsch, 1988). However, the success of such entrepreneurs may in part depend on easy access to high technology products, services, or inventions that are owned or controlled by others. Specifically, the strength of a country's IPR regime influences the ease or difficulty of acquiring someone's innovations from that country (Pathak et al., 2013). Whereas a softer IPR regime that ensures easy access to the latest technological resources could foster entrepreneurial intentions, one that is too stringent may stifle them because of accessibility barriers, or high transaction costs.

For instance, while 3D printing technology is considered to have the potential to change the overall manufacturing paradigm (Hahn et al., 2014), patents on $3 \mathrm{D}$ printing technologies have been cited as expensive for startup entrepreneurs to access. On the other hand, the availability of free Apache server software and open source Java language and other tools for download, makes it relatively easy for an entrepreneur to start a website. Combined with easy access to payment services, such as Paypal, crowdsourcing such as Kickstarter, and labour from platforms like Upwork, entrepreneurs have never had easier access to such resources to start a business.

When an entrepreneur attempts to access the latest technology in order to develop innovations that compete directly with a former employer (that is, spinouts), maximum damage may be caused to the incumbent(s). This can lead the incumbent(s) to respond defensively, by enacting lawsuits, or applying economic pressure through networks. In particular, institutions such as IPRs offer incumbents legal tools to impose heavy costs on new entrants.

In summary, strong IPR regimes may restrict 


\section{A Two-Staged Approach to Technology Entrepreneurship: Differential Effects of Intellectual Property Rights Saurav Pathak \& Etayankara Muralidharan}

accessibility to the latest technology by entrepreneurs who are searching to exploit new combinations or variations of patented and copyrighted components (Pathak et al., 2013).

\section{Proposition 1: Stronger IPR regimes decrease accessibility to the latest technologies and technological resources by entrepreneurs.}

\section{Technology access and TEI}

Explaining the process of innovation as he experienced it during his discovery-making process, Schumpeter (1939) pointed out that innovation is a kind of recombination that involves reconstituting existing resources to create new ones. Nelson and Winter (1982) wrote that, "innovation combines components in a new way, or ... consists in carrying out new combinations". Access to the latest technologies may therefore be a prerequisite for TEI.

Many internet companies are "born global" ventures. As a result, they can often access the latest technologies to source, sell, and market their products, and even develop new ones (Tanev, 2012; Rasmussen \& Tanev, 2015). For example, the easy accessibility of crowdfunding such as Kickstarter allows for the possibility of quick financing (Gedda et al., 2016), electronic job markets allow for specialized employment to be contracted efficiently (Upwork), online 3d printing services allow for small batches of products to be produced (Shapeways), online shopping sites allow for easy access to global buyers (eBay and Amazon), and marketing automation software allows for broad communications reach.

By contrast, without access to the latest available technologies and technological resources, entrepreneurs instead must pursue limited markets. Again, as suggested by knowledge spillover theory, knowledge spillovers from incumbents provide technological opportunities for new entrepreneurs. Such opportunities are among the key drivers of technological change and economic growth (Kydland \& Prescott, 1982). Entrepreneurs with easy access to such know-how are more likely to introduce innovations that incumbents have overlooked (Acs et al., 2009).

Proposition 2: Easy access to the latest technologies and technological resources by entrepreneurs increases TEI.

\section{IPR, TEI, and the mediating role of technology access by} entrepreneurs

Successful TEI, as per knowledge spillover theory, may in part depend on the availability of high technology resources owned or controlled by others. The strength of an IPR regime influences the ease or difficulty in acquiring these resources by new entrepreneurs for recombination purposes, which leads to new productmarket combinations. As mentioned earlier, TE is the process where new applicable knowledge (technology and technological resources) is used by entrepreneurs to create value by developing new product-market combinations. The success of such entrepreneurship is therefore contingent upon accessibility to the latest state of the art technologies and technological resources.

Since the strength of the IPR regime in a country influences the ease or difficulty of acquiring someone else's innovations for recombination purposes, IPR as a contextual influence has a key role in facilitating entrepreneurs' success in effecting TEIs. In particular, IPRs regimes need to provide access to the latest technologies and technological resources for new entrepreneurs, at the same time without these entrepreneurs being in direct competition with the incumbents. Targeting markets that are saturated with similar products is problematic because small entrepreneurs have big disadvantages as compared with large, established companies. In particular, greater access to these technological resources by incumbents is usually enough to allow them to use price wars, exclusive contracts, buyouts, and other such tactics to get rid of the threat of new ventures.

Thus, entrepreneurs are better off to target customers with new products or to target new customers with existing products through effective recombinations of incumbents' technology or technological resources. These, if successfully deployed by a new venture allow it to avoid direct competition with incumbents. For instance, Bower and Christensen (1996) refer to disruptive innovations as those that cater to marginal customers and non-consumers, rather than the mainstream or best customers of incumbents. In the above circumstances, once the latest technologies are accessible by an entrepreneur, strong IPR shifts from being a burden on access to technology and technological resources, to being an asset that helps the entrepreneur protect a new venture and its investments.

At this point, the benefits to incumbents now become available to the innovative entrepreneur as well. Hence, 


\section{A Two-Staged Approach to Technology Entrepreneurship: Differential Effects of Intellectual Property Rights Saurav Pathak \& Etayankara Muralidharan}

for a strong IPR regime to facilitate TEI, the latest technologies and technological resources must be easily accessible to entrepreneurs from the start. In other words, the influence of a strong IPR regime on TEI is indirect, and mediated by the positive influence of the IPR regime on entrepreneurs' access to the latest technologies and technological resources.

Proposition 3: The positive effect of stronger IPR regimes on TEI is indirect, and mediated by an entrepreneur's easy access to the latest technologies and technological resources.

Our conceptual model is presented in Figure 1 below.

\section{Discussion}

As evidence mounts that innovation is a key link between entrepreneurship and economic success leading to growth, scholars have started to narrow in on the antecedents of TEI. This offers fertile ground for new theory development on the contextual influences involved. IPR and their regimes of enforcement have varying effects on different forms of entrepreneurship. Stage-based models of entrepreneurship (Wood \& McKinley, 2010) suggest that research examining entrepreneurial behaviors needs to be specific about the stage that is being studied. While Giones and Miralles (2015) discuss the influence of technology in the two main activities or stages of the entrepreneurship process, that is, value creation and value capture, we present a stage-based approach to TEI that has promise to disentangle the inconclusive nature of the influence of IPR regime strength on TEI. We argue that stricter IPR regimes suppress easy accessibility to the latest technological resources by entrepreneurs, yet if the latest technological resources could be made accessible to entrepreneurs, then stricter IPR regimes would augment using those latest technological resources in TEIs.

In other words, the influence of IPR on TEI is felt via its influence on the easy accessibility of the latest technologies by entrepreneurs in the first place. Combining the two stages into one (as considered in previous research) we believe could be why there were mixed findings regarding the influence of IPR on TE. TE may have been considered from a new product development point of view (as an outcome) rather than being considered as a process. Firms or technologies have been predominantly the level of analysis, but seldom the individual's feasibility of using the latest technologies and the ability to combine them into new products and markets (Giones \& Brem, 2017). Thus, our model suggests that the same institutions can have differing effects across various types of entrepreneurial behaviors.

As such, our proposed model offers several contributions to the entrepreneurship literature examining contextual influences. It contributes to theory building by establishing a way to consider the influence of IPR on technology entrepreneurship using a process perspective (Bailetti et al., 2012). The model specifically contributes to the emerging literature on innovative forms of entrepreneurship, rather than seeking to predict rates of entrepreneurship in general. A specific focus on innovative entrepreneurs allows for a more fine-grained analysis of institutional influences. Our conceptual model demonstrates that the same institutions can have different or even opposite effects on various stages of entrepreneurship.

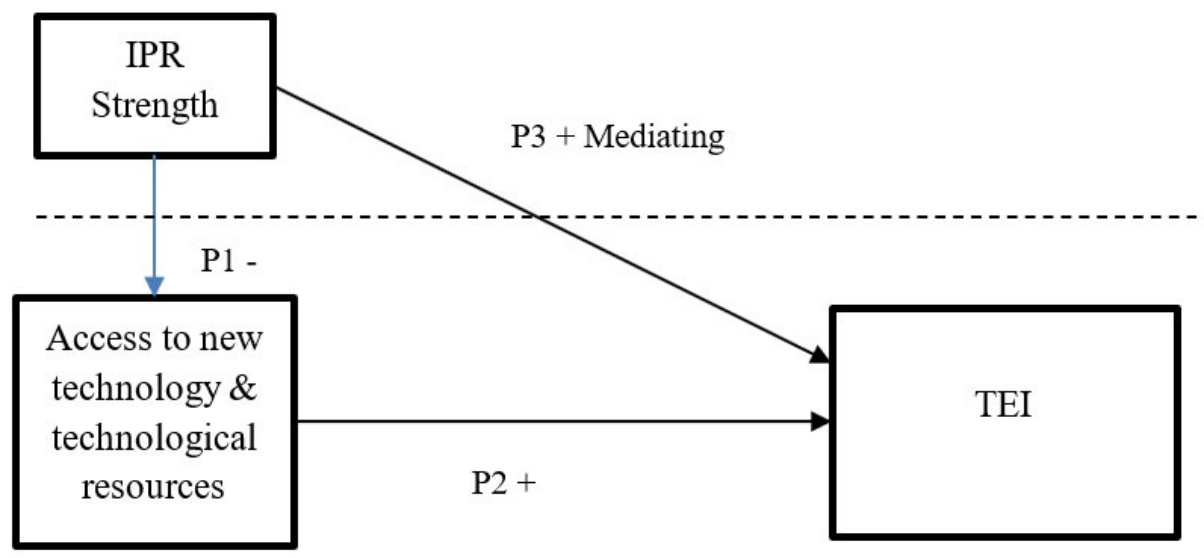

Figure 1. Mediation Model 


\section{A Two-Staged Approach to Technology Entrepreneurship: Differential Effects of Intellectual Property Rights Saurav Pathak \& Etayankara Muralidharan}

\section{Implications for policy and practice}

Innovation and entrepreneurship are often seen as important and required factors that contribute to growth in society (Braunerhjelm et al., 2010). Policy makers, while talking about 'innovation systems', 'innovation strategies', 'innovation systems', etc., emphasize the role of R\&D in the advancement of new knowledge, yet may also give insufficient attention to the aspects of growth in society such as commercialization and business creation (Landström et al., 2013). Our conceptual framework, while emphasizing the business formation aspect, implies that policy-makers can adjust the strength of IPR in favor of innovative entrepreneurs, though it comes at the expense of less innovative entrepreneurs.

Implications for practice are relevant to entrepreneurs themselves. Entrepreneurs should first recognize what importance the use of the latest technologies has for their ventures. This is important so that they can become candidates for more innovations. Once they have attained a technology setup that utilizes the latest available technologies and resources, they can focus on innovation, such as pursuing new product-market combinations. In particular, at this stage, IPR shifts from being a burden on access to the latest technological resources and components, to being an asset that helps the firm protect its investments.

Thus, when thinking and researching about IPR to gain access to technology, entrepreneurs should not be too deflated, as it is likely they will be able to benefit from IPR too, in due time. This is particularly relevant when studying the effects of IPR across countries. IPR may have differential influences across developed and emerging economies. Emerging economies often lag in technology and may have barriers to technology adoption that prevent their indigenous entrepreneurs from acquiring and using the latest available technologies in their ventures.

\section{Future Research}

Future research examining the influence of contextual factors on entrepreneurial behaviors may need to be specific about the type of behavior being studied. For example, IPR support in a startup ecosystem may be adapted to different types of high-technology startups (Wallin et al., 2016). Further, policy implications drawn from such studies, if they are based on crude measures of entrepreneurial behaviors, may be counterproductive, depending on the type of entrepreneurship that is desired.
Our conceptual model could be strengthened by incorporating other formal institutions, such as regulations, the role of a country's political system (Laplume et al., 2014), and informal institutions that are culturally embedded (Pathak \& Muralidharan, 2016; Muralidharan \& Pathak, 2017; Muralidharan \& Pathak, 2018). Further, acquiring licenses to older technologies may also be considered a viable strategy for TE, although this strategy needs to be properly evaluated to avoid issues that could outweigh perceived value (Smith, 2013). The availability of older technologies and their potential value may also be considered in our conceptual model by future research. Innovation processes are different for complex products and systems compared to mass-produced consumer products, where most of the conventional wisdom on innovation resides (Hobday et al., 2000). In the innovation processes of such systems, the user and the developer are mutually involved in the innovation processes (Hobday et al., 2005).

In considering our model, future research may need to clearly distinguish entrepreneurs (as developers and users of new technology) from those that source and use new technologies for TEIs in theorizing the role of IPR regimes. Inter-firm collaborations could serve to reduce the costs for adopting new technologies by TEI entrepreneurs. For example, transaction costs to access new technologies may be reduced through modern patent pools, where a patent pool is an agreement between two or more parties to license their patents to one another (Vakil, 2016). Similarly, as part of strategy, firms can make their IPRs available to others for use at a low cost in order to facilitate complementary innovations, such as in the case of open source software (Wen et al., 2015). Subsequent research may need to factor in the above conditions for future theorizing. Finally, our model assumes that the process of TEI necessarily uses new technology and technological resources. Future conceptualization may need to factor in disruptive innovations where entrepreneurs with fewer resources were able to successfully challenge established businesses (Christensen et al., 2015).

\section{Conclusion}

IPR in particular seems to be an incumbent's game. They get the lion's share of the benefits created by IPR. However, in understanding TE as a stage-based process, in this paper we suggested that although IPR regimes may at first suppress the ease of accessibility to the latest technologies for entrepreneurs, if such technologies are 


\section{A Two-Staged Approach to Technology Entrepreneurship: Differential Effects of Intellectual Property Rights Saurav Pathak \& Etayankara Muralidharan}

eventually made available to them, then stricter IPR regimes will likely augment their use in developing TEI. Having easy access to the latest technologies is therefore an important precursor for entrepreneurs to TEI. Once an entrepreneur gains access to the latest technologies and begins to innovate, institutions often shift from being constraints to the entrepreneur into being facilitators.

\section{References}

Acs, Z., \& Audretsch, D. 1988. Innovations in large and small firms. American Economic Review, 78(4): 678690.

Acs, Z., Braunerhjelm, P., Audretsch, D., \& Carlsson, B. 2009. The knowledge spillover theory of entrepreneurship. Small Business Economics, 32(1): 15-30.

Acs, Z.J., \& Sanders, M. 2008. Intellectual property rights and the knowledge spillover theory of entrepreneurship (No. 2008, 069). Jena economic research papers. Jena Germany: Max Planck Institute of Economics.

Autio, E., \& Acs, Z. 2010. Intellectual property protection and the formation of entrepreneurial growth aspirations. Strategic Entrepreneurship Journal, 4(3): 234-251.

Bailetti, T. 2012. Technology entrepreneurship: overview, definition, and distinctive aspects. Technology Innovation Management Review, 2(2): 512.

Bailetti, T., Bot, S.D., Duxbury, T., Hudson, D., McPhee, C., Muegge, S., ... \& Westerlund, M. 2012. An overview of four issues on technology entrepreneurship in the TIM Review. Technology Innovation Management Review, 2(5): 28-34.

Bhave, M.P. 1994. A process model of entrepreneurial venture creation. Journal of Business Venturing, 9(3): 223-242.

Bower, J.L., \& Christensen, C.M. 1996. Disruptive technologies: Catching the wave. The Journal of Product Innovation Management, 1(13): 75-76.

Braunerhjelm, P., Acs, Z.J., Audretsch, D.B., \& Carlsson, B. 2010. The missing link: knowledge diffusion and entrepreneurship in endogenous growth. Small Business Economics, 34(2): 105-125.

Christensen, C.M., Raynor, M.E., \& McDonald, R. 2015. What is disruptive innovation. Harvard Business Review, 93(12): 44-53.

Damanpour, F., \& Schneider, M. 2006. Phases of the adoption of innovation in organizations: effects of environment, organization and top managers. British Journal of Management, 17(3): 215-236.
Douglas, E.J., \& Shepherd, D.A. 2002. Self-employment as a career choice: Attitudes, entrepreneurial intentions, and utility maximization. Entrepreneurship Theory and Practice, 26(3): 81-90.

Estrin, S., Korosteleva, J., \& Mickiewicz, T. 2013. Which institutions encourage entrepreneurial growth aspirations? Journal of Business Venturing, 28(4): 564580.

Fagerberg, J. 1987. A technology gap approach to why growth rates differ. Research Policy, 16(2-4): 87-99.

Fleming, L. 2001. Recombinant uncertainty in technological search. Management Science, 47(1): 117-132.

Gedda, D., Nilsson, B., Sathen, Z., \& Solberg Soilen, K. 2016. Crowdfunding: Finding the Optimal Platform for Funders and Entrepreneurs. Technology Innovation Management Review, 6(3): 31-40.

Giones, F., \& Brem, A. 2017. Digital technology entrepreneurship: A definition and research agenda. Technology Innovation Management Review, 7(5): 4451.

Giones, F., \& Miralles, F. 2015. Do Actions Matter More than Resources? A Signalling Theory Perspective on the Technology Entrepreneurship Process. Technology Innovation Management Review, 5(3): 3945.

Giones, F., Zhou, Z., Miralles, F., \& Katzy, B. 2013. From Ideas to Opportunities: Exploring the Construction of Technology-Based Entrepreneurial Opportunities. Technology Innovation Management Review, 3(6): $13-0$.

Glass, A.J., \& Saggi, K. 2002. Intellectual property rights and foreign direct investment. Journal of International Economics, 56(2): 387-410.

Greenhalgh, T., Robert, G., Bate, P., Macfarlane, F., \& Kyriakidou, O. 2008. Diffusion of Innovations in Health Service Organisations: a systematic literature review. John Wiley \& Sons.

Hahn, F., Jensen, S., \& Tanev, S. 2014. Disruptive innovation vs. disruptive technology: The disruptive potential of the value propositions of 3D printing technology startups. Technology Innovation Management Review, 4(12).

Hameed, M.A., Counsell, S., \& Swift, S. 2012. A conceptual model for the process of IT innovation adoption in organizations. Journal of Engineering and Technology Management, 29(3): 358-390.

Hartmann, D. 2014. Turning Technology into Business Using University Patents. Technology Innovation Management Review, 4(12): 37-43.

Hanks, S.H., Watson, C.J., Jansen, E., \& Chandler, G.N. 1994. Tightening the life-cycle construct: A taxonomic study of growth stage configurations in hightechnology organizations. Entrepreneurship Theory and Practice, 18(2): 5-29.

Henry, D.J. 2011. Intellectual Property Rights: Unlocking 


\section{A Two-Staged Approach to Technology Entrepreneurship: Differential Effects of Intellectual Property Rights Saurav Pathak \& Etayankara Muralidharan}

the Value of this New Asset Class. Technology Innovation Management Review, 1(3): 23-28.

Hobday, M., Rush, H., \& Joe, T. 2000. Innovation in complex products and systems. Research Policy, 29(78): 793-804.

Hobday, M., Davies, A., \& Prencipe, A. 2005. Systems integration: a core capability of the modern corporation. Industrial and Corporate Change, 14(6): $1109-1143$.

Kazanjian, R.K., \& Drazin, R. 1990. A stage-contingent model of design and growth for technology based new ventures. Journal of Business Venturing, 5(3): $137-150$

Korunka, C., Frank, H., Lueger, M., \& Mugler, J. 2003. The entrepreneurial personality in the context of resources, environment, and the startup process - A configurational approach. Entrepreneurship Theory and Practice, 28(1): 23-42.

Kydland, F.E., \& Prescott, E.C. 1982. Time to build and aggregate fluctuations. Econometrica, 50(6): 13451370.

Landström, H., Åström, F., \& Harirchi, G. 2013. Innovation and entrepreneurship studies: one or two fields of research? International Entrepreneurship and Management Journal, 1-17.

Laplume, A.O., Pathak, S., \& Xavier-Oliveira, E. 2014. The politics of intellectual property rights regimes: An empirical study of new technology use in entrepreneurship. Technovation, 34(12): 807-816.

Muralidharan, E., \& Pathak, S. 2017. Informal institutions and international entrepreneurship. International Business Review, 26(2): 288-302.

Muralidharan, E., \& Pathak, S. 2018. Sustainability, transformational leadership, and social entrepreneurship. Sustainability, 10(2): 567.

Nystrom, P.C., Ramamurthy, K., \& Wilson, A.L. 2002. Organizational context, climate and innovativeness: adoption of imaging technology. Journal of Engineering and Technology Management, 19(3-4): 221-247.

Pathak, S., \& Muralidharan, E. 2016. Informal institutions and their comparative influences on social and commercial entrepreneurship: The role of in group collectivism and interpersonal trust. Journal of Small Business Management, 54(sup1): 168-188.

Pathak, S., Muralidharan, E., \& Laplume, A. 2014. Home country factors and the decision to internationalize technology-based new ventures: A multi-level study of early-stage entrepreneurs. Frontiers of Entrepreneurship Research, 34 (19): 1.

Pathak, S., Xavier-Oliveira, E., \& Laplume, A.O. 2013. Influence of intellectual property, foreign investment, and technological adoption on technology entrepreneurship. Journal of Business Research, 66(10): 2090-2101.

Rasmussen, E.S., \& Tanev, S. 2015. The Emergence of the Lean Global Startup as a New Type of Firm. Technology Innovation Management Review, 5(11): 12-19.

Rogers, E.M. 1995. Diffusion of Innovations. New York: Free Press.

Schumpeter, J.A. 1939. Business Cycles: A Theoretical, Historical and Statistical Analysis of the Capitalist Process. (2 Vols.) New York: McGraw Hill.

Schumpeter, J.A. 1912. The Theory of Economic Development: An Inquiry into Profits, Capital, Credit, Interest, and the Business Cycle. Cambridge: Harvard University Press.

Smith, D. 2013. Leveraging old intellectual property to accelerate technology entrepreneurship. Technology Innovation Management Review, 3(6): 21-27.

Tanev, S. 2012. Global from the Start: The Characteristics of Born-Global Firms in the Technology Sector. Technology Innovation Management Review, 2(3): 5-8.

Vakili, K. 2016. Collaborative promotion of technology standards and the impact on innovation, industry structure, and organizational capabilities: Evidence from modern patent pools. Organization Science, 27(6): 1504-1524.

Wallin, A., Still, K., \& Henttonen, K. 2016. Entrepreneurial Growth Ambitions: The Case of Finnish Technology Startups. Technology Innovation Management Review, 6(10): 5-16.

Welter, F. 2011. Contextualizing EntrepreneurshipConceptual Challenges and Ways Forward. Entrepreneurship Theory and Practice, 35(1): 165-184.

Wen, W., Ceccagnoli, M., \& Forman, C. 2016. Opening up intellectual property strategy: Implications for open source software entry by start-up firms. Management Science, 62(9): 2668-2691.

Westerlund, M., Leminen, S., \& Rajahonka, M. 2014. Designing Business Models for the Internet of Things. Technology Innovation Management Review, 4(7): 514.

Wood, M.S., \& McKinley, W. 2010. The production of entrepreneurial opportunity: a constructivist perspective. Strategic Entrepreneurship Journal, 4(1): 66-84. 


\section{A Two-Staged Approach to Technology Entrepreneurship: Differential Effects of Intellectual Property Rights Saurav Pathak \& Etayankara Muralidharan}

\begin{abstract}
About the Authors
Saurav Pathak, is an associate professor of innovation and entrepreneurship in the Williams College of Business at Xavier University. Pathak received his first Ph.D., in mechanical engineering from the University of Florida (2007) and another in entrepreneurship from the Imperial College Business School, London (2011). After his doctorate from University of Florida in 2007, he returned to India and was part of a tech-start-up named Zeus Numerix Private Limited that was incubated in the prestigious Indian Institute of Technology, Mumbai. There he held the position of Lead Scientist and was instrumental in developing simulation software for India's aviation industry and commercial nuclear power plants. He also holds a master's in mechanical engineering (ME) degree from Ohio University (2003) and a Bachelor in ME from Birla Institute of Technology, India (2001). Dr. Pathak's research revolves around cross-country comparative entrepreneurship and focuses on examining the influences of higher-order contextual factors on individual-level entrepreneurial behaviors. Recently, he has started looking into how culture-specific emotional intelligence, including perceived wellbeing, shapes such behaviors differently across cultures. His ongoing research projects also include predicting entrepreneurial coping strategies and selfcontrol based on entrepreneur's level of emotional intelligence.
\end{abstract}

Etayankara Muralidharan is an Associate Professor of Management at MacEwan University, Canada. He received his $\mathrm{PhD}$ in 2013 from the University of Manitoba in Canada. His research interests are in organizational crisis management and entrepreneurship. His research has been recently published in Journal Business Ethics, Business \& Society, Sustainability, Cross-Cultural Management, Journal of Small Business Management, International Business Review, Thunderbird International Business Review, Management Research Review, International Journal of Innovation \& Technology Management, Current Topics in Management, and has been presented at and appeared in the proceedings of the Academy of Management, Academy of International Business, Babson Entrepreneurship Conference (BCERC) and the Administrative Sciences Association of Canada.
Citation: Pathak, S. \& Muralidharan, E. 2020. A Two-Staged Approach to Technology Entrepreneurship: Differential Effects of Intellectual Property Rights. Technology Innovation Management Review, 10(6): 5-13.

http://doi.org/10.22215/timreview/1364

Keywords: Innovation, technology, entrepreneurship, intellectual property rights. 